ENTREPRENEURSHIP AND SUSTAINABILITY ISSUES

ISSN 2345-0282 (online) http://jssidoi.org/jesi/

2019 Volume 7 Number 2 (December)

http://doi.org/10.9770/jesi.2019.7.2(31)

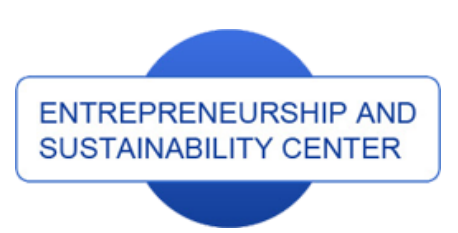

Publisher

http://jssidoi.org/esc/home

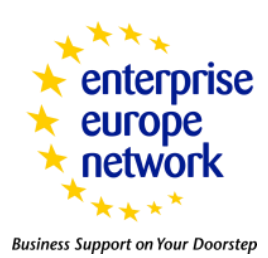

CASPA

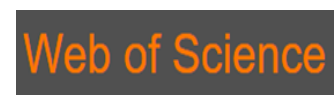

Clarivate
Analytics

\title{
MULTIPLE DISCRIMINATION AND INEQUALITY: A COMPARATIVE ANALYSIS OF THE EUROPEAN COURTS CASE LAW IN THE CONTEXT OF SUSTAINABLE BUSINESS DEVELOPMENT
}

\author{
Raimonda Bublienè1, Vaidas Jurkevičius ${ }^{2}$ \\ ${ }^{1,2}$ Mykolas Romeris University, Ateities st. 20, 08303, Vilnius, Lithuania \\ E-mails: ${ }^{1}$ rabubliene@stud.mruni.eu ; ${ }^{2}$ vaidas.jurkevicius@mruni.eu
}

Received 18 May 2019; accepted 25 September 2019; published 15 December 2019

\begin{abstract}
In the light of social and economic development multidimensional reality and inequality, the concept of multiple discrimination plays an important role in ensuring to achieve gender equality to stimulate employment and sustainability of business. Such situations in which a person is discriminated on several grounds emerge multiple discrimination. The multiple discrimination complexity redress gender intersectional inequality towards sustainable development and remains as a key challenge. The difficulty with the multiple and intersectional discrimination lies in the lack of awareness and consistent definition of multiple discrimination, patchy legal framework of antidiscrimination law and adequate judicial response. Therefore, one of Sustainable Development Goals encourage achieving gender equality and empowering all women and girls to ensure equality and non-discrimination, women's full and effective participation and equal opportunities for leadership at all levels of decision-making in political, economic and public life. This article is deemed to provide a comprehensive analysis of the multiple, intersectional discrimination based on complex inequality and discusses case law of the Court of Justice of the European Union and European Court of Human Rights from a comparative perspective. Discuss the multiple discrimination interrelationship between the human and fundamental rights framework and the Sustainable Development Goals. A conclusion is made that recognition of the multiple, intersectional discrimination will be an efficient mean for further sustainable business development and combine all ground of discrimination especially in the case of complex inequality at the area of employment.
\end{abstract}

Keywords: multiple discrimination; anti-discrimination law; sustainable development; employment

Reference to this paper should be made as follows: Bublienè, R., Jurkevičius, V. 2019. Multiple discrimination and inequality: a comparative analysis of the European Courts case law in the context of sustainable business development. Enterpreunership and Sustainability Issues, 7(2), 1246-1257. http://doi.org/10.9770/jesi.2019.7.2(31)

JEL Classifications: K10, K31, K38

Additional disciplines: law

\section{Introduction}

Equality and non-discrimination are fundamental values of the European Union (hereinafter EU) and protected by the anti-discrimination legal framework. These fundamental values consolidated in the constitutional traditions of 


\section{ENTREPRENEURSHIP AND SUSTAINABILITY ISSUES}

ISSN 2345-0282 (online) http://jssidoi.org/jesi/

2019 Volume 7 Number 2 (December)

http://doi.org/10.9770/jesi.2019.7.2(31)

all Member States and under international obligations. EU Member States are party to the following human rights treaties: European Convention for the Protection of Human Rights and Fundamental Freedoms (1950) (hereinafter ECHR), International Covenant on Civil and Political Rights (1966) (hereinafter ICCPR), Convention on the Elimination of All Forms of Discrimination against Women (1979), Convention on the Rights of Persons with Disabilities (2006) (hereinafter CRPD), all of which contain a prohibition on discrimination. Also, the 2030 Agenda for Sustainable Development (2015), adopted by the United Nations General Assembly and its 17 Sustainable Development Goals (hereinafter SDGs), have given a new insight to global efforts for achieving sustainable development. The sustainable development is conceptualised under three equal and interconnected dimensions: economic, environmental and social.

SDGs call promote peaceful and inclusive societies for sustainable development, provide access to justice for all and build effective, accountable and inclusive institutions at all levels the achievement of full human potential and sustainable development is not possible if one-half of humanity continues to be denied its full human rights and opportunities. Following the SDGs compulsory to ensure inclusive and equitable business sustainability, important to increase the number of youth and adults who have relevant skills, including technical and vocational skills, for employment, decent jobs and entrepreneurship (United Nations General Assembly 2015). Goal 5 aims to achieve gender equality by ending all forms of discrimination, violence and any harmful practices against women and girls in the public and private spheres, it also calls for the full participation of women and equal opportunities for leadership at all levels of political and economic decision-making (Eurostat 2019).

The EU has highlighted the interconnectedness of all three dimensions of sustainable development and the universal applicability of SDGs, stressing that eradicating poverty and reducing inequality should be a major focus (European Union Agency for Fundamental Rights 2019; Schouten 2019).

Therefore, for example, cases regarding discrimination in the field of employment - EU citizens Muslim women wearing Islamic headscarf were dismissed from work and the following cases involving harmful stereotypes based not only on religion, but first of all on gender and also on race. Such situations based on several grounds pertains intersection between the grounds and cause intersectional discrimination. Examination discrimination from the perspective of insolation of grounds fails to tackle adequately various manifestations of inequality.

In the Fundamental Rights Report, European Union Agency for Fundamental Rights (2019) highlighted, that the EU continued to engage with Member States to support their efforts to advance lesbian, gay, bisexual, transgender and intersex (LGBTI) equality, and several Member States introduced legal and policy measures to that effect. Bans on religious clothing and symbols continued to trigger controversies, meanwhile, the EU and Member States took diverse steps to strengthen the collection and use of equality data, and a range of studies and surveys published provided evidence on the extent and forms of discrimination that people experience in the EU (European Union Agency for Fundamental Rights 2019). Ensuring high employment rates for both men and women is one of the EU's key targets (Eurostat 2019).

The aim of this article is to analyse the legal framework of EU anti-discrimination law and the Court of Justice of the European Union and European Court of Human Rights (hereinafter European Courts) decisions based on a single ground cases in the light of intersection and multiple discrimination. Controversies regarding EU policy and the European Courts decisions are presented in the current research since the issue of multiple discrimination and discrimination grounds intersection is problematic in EU legal framework. Some attention in the Court of Justice of the European Union (hereinafter CJEU) and European Court of Human Rights (hereinafter ECtHR) jurisprudence has been shown already to the multiple discrimination. The article also provides a comparative case law research, which is particularly important in order to ensure the possibility of full realization of the equality and to tackle all forms of discrimination, including multiple and intersectional discrimination and to ensure SDGs. 


\section{ENTREPRENEURSHIP AND SUSTAINABILITY ISSUES}

ISSN 2345-0282 (online) http://jssidoi.org/jesi/

2019 Volume 7 Number 2 (December)

http://doi.org/10.9770/jesi.2019.7.2(31)

The paper analysis based on methodological regulations of studies of law, matching ideas of theories of normative and case law. The main data collection method used during the study was method of conceptual analysis. Taking into account the character of the study, the most important data analysis method in this paper is comparative when revealing divergences in the case law of the European Courts.

\section{The European anti-discrimination legal framework and the concept of multiple discrimination}

In the EU policy regulating equality and non-discrimination there is no settled single consensual terminology or concept of consistent multiple and intersectional discrimination. At the legislative setting for the first-time multiple discrimination problem was recognized by the recital (14) of Race Equality Directive (2000) (hereinafter RED) and recital (3) of Employment Equality Directive (2000) (hereinafter EED) stating the aim to eliminate inequalities, and to promote equality between men and women, especially since women are often the victims of multiple discrimination. According Handbook on European non-discrimination law (European Union Agency for Fundamental Rights 2018), multiple discrimination describes discrimination that takes place based on several grounds operating separately; intersectional discrimination describes a situation where several grounds operate and interact with each other at the same time in such a way that they are inseparable and produce specific types of discrimination.

With the Equal Treatment Directive proposal (2008) European Commission was willing to tackle define and provide effective remedies for complex inequality and multiple discrimination. The proposal was on implementing the principle of equal treatment outside the employment, irrespective of age, disability, sexual orientation or religious belief, which aims at extending protection against discrimination through a horizontal approach. Remaining problem is the inequality for the protecting non-discrimination grounds of different areas of life. EED prohibited discrimination on the grounds of sexual orientation, religion or belief, age and disability, in the area of employment and the RED introduced prohibition of discrimination on the grounds of race or ethnicity in the context of employment, but also in accessing the welfare system and social security, as well as goods and services. Gender Equality Directive (recast) (2006) guarantees equal treatment only in area of social security, and not to the broader welfare system, such as social protection and access to healthcare and education. Although sexual orientation, religious belief, disability and age are only protected grounds in the context of employment, a proposal of Equal Treatment Directive to extend protection to other areas, such as accessing goods and services is currently being debated in EU institutions (European Union Agency for Fundamental Rights 2018).

Table 1. EU legal framework for equal treatment and anti-discrimination

\begin{tabular}{|c|c|c|c|c|c|c|}
\hline Areas & Race & Gender & Religion & Age & Disability & $\begin{array}{c}\text { Sexual } \\
\text { Orientation }\end{array}$ \\
\hline Employment & Yes & Yes & Yes & Yes & Yes & Yes \\
\hline Education & Yes & No & No & No & No & No \\
\hline Goods \& Services, Houssing & Yes & Yes & No & No & No & No \\
\hline Social Protection, Healtcare & Yes & Yes & No & No & No & No \\
\hline Social Advantages & Yes & No & No & No & No & No \\
\hline
\end{tabular}

Source: European Union Agency for Fundamental Rights (2018)

Thus, multiple discrimination was mentioned in five Resolutions adopted by the European Parliament in 2016. The European Parliament Resolution on application of EED establishing a general framework for equal treatment in employment and occupation (2016) notes and indicated that discrimination because of religion or belief, racial or ethnic origin was always considered to be of the intersectional type and those certain religious minority groups 


\section{ENTREPRENEURSHIP AND SUSTAINABILITY ISSUES}

ISSN 2345-0282 (online) http://jssidoi.org/jesi/

2019 Volume 7 Number 2 (December)

http://doi.org/10.9770/jesi.2019.7.2(31)

were particularly discriminated against, on the grounds of religion in employment market, as it was presented in the national and European scientific investigations. First, in the EU studies made by the Fundamental Rights Agency, the participants of the employment market, of which quite often, women were identified as a vulnerable group of discrimination due to gender and race. It is possible to state that, essentially for this group in Europe, there has been given the most attention, though it does not mean that this group is very vulnerable. The European Parliament on application of EED establishing a general framework for equal treatment in employment and occupation (2016), have concerned the considerations on the data of the studies on the religious groups, discriminated against in employment market, they are Jews, Sikhs and Muslims (and especially women); it is recommended to accept European programs for national strategies which would combat anti-Semitism and Islamophobia.

European Parliament Resolution on refugees: social inclusion and integration into the labour market (2016), on social inclusion and integration into the labour market designated that the situation of women's refugee camps in Europe was of particular concern as well as their living conditions and hygiene. It was indicated that women's healthcare needs were different from men's, because they more often faced multiple risks, including gender-based violence, reproductive health issues, and cultural obstacles, in order to access health care, besides that it was considered that the policy of the mentioned above issues could not be gender neutral. The document calls on the Member States to use the Rights, Equality and Citizenship program funds for diversity education and training and delivering information for refugees and migrants wishing to enter the labour market as well as about their rights as employees, lest they become victims of exploitation and employers. It is noted there that the problem of multiple discrimination has to be considered within the policy of migration and integration.

European Parliament Resolution on the implementation of the UN Convention on the Rights of Persons with Disabilities, with special regard to the Concluding Observations of the UN CRPD Committee (2016) indicated that EU had more women with disabilities than men; women with disabilities often faced multiple discrimination. They faced significant obstacles in the exercise of their fundamental rights and freedoms, such as the right to education and employment; it could also lead to social exclusion and psychological trauma. Disabled people were a very diverse group and because women, children, seniors and persons with complex support needs faced additional challenges and multiple discrimination of various forms. The document encouraged to take actions and fight against all kinds of discrimination and multiple discrimination as well as discrimination due to links and connections and intersectional discrimination due to disability. Especially taking into consideration women with disabilities and children, older people, people with complex support needs, including those with intellectual and psychosocial problems, as well as those whose disabilities tend to change over time.

Whereas the European Parliament Resolution on poverty: a gender perspective (2016) highlighted that persons living at risk of poverty, mostly women, were even more vulnerable in the labour market and in social security, especially the groups facing multiple discrimination; studies conducted by the EU Fundamental Rights Agency identified the most vulnerable groups of multiple discrimination that were the following, namely women with disabilities, elderly women, young ethnic minority men, disabled homosexuals and transgender people, elderly homosexuals and transgender people, young homosexuals and transgender people and elderly people with disabilities.

Studies made by the governmental and non-governmental organizations, recognized that people could belong or belong to several less-privileged groups at the same time and nearly all institutions had a tendency to concern themselves with some form of discrimination. Resolution of the Parliamentary Assembly of the Council of Europe Multiple discrimination against Muslim women in Europe: for equal opportunities (2012) underlines that in the Member States of European Union, in which a minority of the population practices Islam, Muslim women are often the victims of stereotypes because of their religious beliefs. Their only aspect that defines their identity 


\section{ENTREPRENEURSHIP AND SUSTAINABILITY ISSUES}

ISSN 2345-0282 (online) http://jssidoi.org/jesi/

2019 Volume 7 Number 2 (December)

http://doi.org/10.9770/jesi.2019.7.2(31)

together with the publishing laws on Muslim women, the greatest attention is paid to women's outfit headscarves or worn veils instead of such issues as non-discrimination and equal opportunities.

This preference is reflected in European Parliament Resolution on application of EED establishing a general framework for equal treatment in employment and occupation (2016), where it was noted that 'it is important to reach agreement as soon as possible'. Besides that, (European Parliament) called on the Council 'to find a way out of this deadlock in order to move towards a pragmatic solution and to speed up the horizontal EU antidiscrimination directive, which in 2008 was proposed by the Commission and voted by Parliament, as an approval without further delay'. This is a prerequisite for ensuring a consolidated and coherent EU legal framework that protects against discrimination on the grounds of religion and belief, disability, age and sexual orientation outside employment. Hence, it is noted there, that according to the European Union Agency for Fundamental Rights, all forms of discrimination, including multiple and intersectional discrimination, severely handicaps, the use of human capital and hampers in career development.

Both Article 14 of the ECHR and additional Protocol No. 12 under ECHR law prohibit discrimination on a large number of grounds, making a claim on more than one ground theoretically possible, furthermore, the nonexhaustive list of grounds of discrimination allows the ECtHR to extend and include grounds not expressly mentioned (European Union Agency for Fundamental Rights 2018). While ECtHR does not use the terms of multiple or intersectional discrimination.

\section{Multiple discrimination signs at the case law of CJEU}

According the research there are ten cases so far decided by the CJEU in which claims of discrimination invoking multiple grounds, eight cases with two grounds and two cases with 3 grounds, eliminating the cases that have been rejected or dismissed, there are left seven multiple discrimination cases (Xenidis 2018). Xenidis (2018) points that only in five cases multiple grounds were really taken into account and the Court of Justice either did not examine the multiple discrimination claim on substance or formally declined to construct a targeted doctrinal framework to access multiple discrimination.

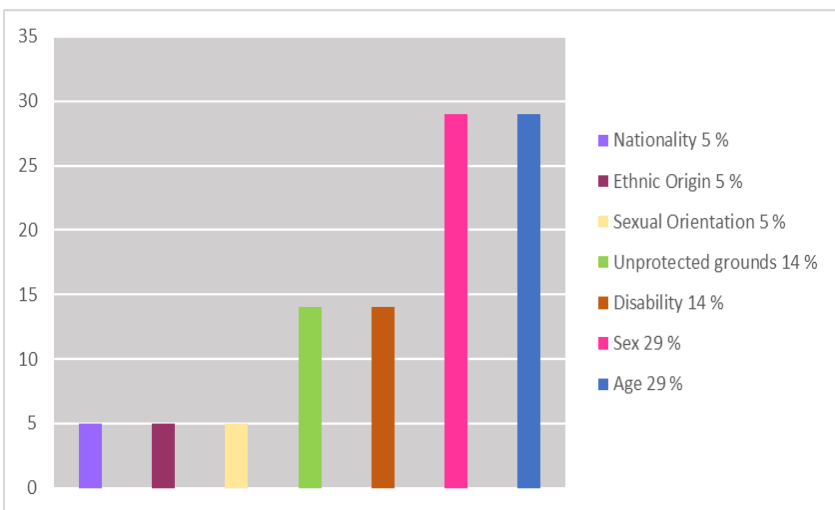

Fig.1. Grounds invoked from 10 cases brought on multiple grounds at the CJEU from 2007 to 2017

Source: Xenidis (2018)

It should be noted, that some cases, which have been submitted for a single ground to CJEU bear the aspects of multiple discrimination and could be examined as the cases of multiple discrimination. Achbita (2017) and Bougnaoui (2017) cases have been the first cases submitted before the Court of Justice on grounds of religion or belief. The situation in those cases is considered very analogous, the issues raised deals with the issues of employees, citizens of EU, Islamic headscarf in the workplace. The cases have been brought to the CJEU as a 


\section{ENTREPRENEURSHIP AND SUSTAINABILITY ISSUES}

ISSN 2345-0282 (online) http://jssidoi.org/jesi/

2019 Volume 7 Number 2 (December)

http://doi.org/10.9770/jesi.2019.7.2(31)

single ground of discrimination based on religion or belief, but when assessing the situation based on the harmful stereotypes formed, the discrimination may be evaluated when based on racial or ethnic origin or gender grounds in the context related to multiple intersectional discrimination.

In the case on Samira Achbita v. G4S Secure Solutions NV (2017), the request for a preliminary ruling from the national court, against the employer's interference and ban for his employees at workplaces to wear symbols of philosophical, political or religious beliefs and perform rites related to those beliefs. Such a ban on a Muslim wearing a scarf at the workplace, really constitute direct discrimination. S. Achbita, Muslim, was employed by the company on a permanent contract. This company had an unwritten rule that employees should not wear any visible symbols of their philosophical, political or religious beliefs in the workplace.

Having worked in the company for three years, S. Achbita informed the manager that she was intending to tie an Islamic headscarf during work; she was informed that the scarf tie would not be tolerated because it was contrary to company neutrality policy. The company approved the amendment of the Rules of Procedure in which it was stated that the employees were prohibited from wearing visible symbols of their philosophical, political or religious beliefs in the workplace. The plaintiff was dismissed because of her strong position as a Muslim to tie an Islamic headscarf in the workplace.

The conclusion presented by Advocate General Kokott (2016) stated that Ms. Achbita, like some other Muslims, wore a headscarf for religious reasons and there was no reason to question her religious motivation. She considered that taking into consideration the case law of the ECtHR related to Article 9 of the ECHR and the practice of the majority of national courts and institutions. The Court of Justice should also regard that as sufficient interaction with religion, and therefore the examined case fell within the material scope of the prohibition of discrimination on grounds of religion laid down in EU law.

The Opinion of Advocate General Juliane Kokott (2016) considered that prohibiting Muslim workers from wearing an Islamic headscarf at work was not direct discrimination on the grounds of religion on the grounds. The prohibition was a general corporate rule that prohibited the wearing of visible political, philosophical and religious signs at work and was not based on the stereotypes or prejudices in terms of one or some particular religions or religious beliefs. At the same time, however, the emphasis was on 'such a ban may constitute indirect discrimination on grounds of religion, such discrimination may be justified in order to pursue the employer's policy of religion and belief neutrality, provided that the principle of proportionality is respected' (Kokott 2016).

CJEU in its judgment stated that the ban on the wearing of an Islamic headscarf, stemming from a private company code of practice which prohibited wearing any visible symbol of philosophical, political or religious beliefs in the workplace, did not constitute direct discrimination on the basis of religion or belief. Also noticeable is the fact, that such a rule of procedure set up by a private company may create indirect discrimination, if it has been determined that due to the neutral duty prescribed in it. In reality the persons of a particular religion or belief would be disadvantaged in some respects, unless such an obligation is objectively justified by a legitimate aim and therefore the Court of Justice has left it to the national court to decide (Samira Achbita v. G4S Secure Solutions NV 2017).

Asma Bougnaoui v. Micropole SA (2017) when a reference for a preliminary ruling from the national court was submitted because of A. Bougnaoui dismissal for not refusing to associate with an Islamic headscarf. When providing services to Micropole SA company clients and the employer's desire to take into account the wishes of the client that the services of that employer should no longer be provided by an employee wearing an Islamic headscarf, was an essential and decisive professional requirement. At the time of her recruitment, the applicant was informed that her freedom of expression was respected, as well as personal religious belief, however, she would not be able to wear head dress when working with clients inside or outside the company. On dismissal, A. 


\section{ENTREPRENEURSHIP AND SUSTAINABILITY ISSUES}

ISSN 2345-0282 (online) http://jssidoi.org/jesi/

2019 Volume 7 Number 2 (December)

http://doi.org/10.9770/jesi.2019.7.2(31)

Bougnaoui was informed on the fact that the wearing of the Islamic headscarf caused certain inconvenience to the company's customers and did not comply with the necessary principle of neutrality in relation to the company's customers.

Advocate General Eleanor Sharpston (2016), in a similar case reached a different conclusion from Advocate General Juliane Kokott. She proposed 'the rule in the place of work of a company which prohibits employees of a company from wearing religious signs or clothing when communicating with customers of a company and shall be deemed to be direct discrimination on grounds of religion or belief and not subject to derogations from the prohibition of direct discrimination on grounds of religion or belief ${ }^{6}$. She considered that such discrimination could not be justified or considered to be in the employer's legitimate interest or proportionate purpose (Sharpston 2016).

In this case, the CJEU states that Member States may provide those differences of treatment in respect of a characteristic related to one of the grounds referred to in Article 1 of the EED and they do not constitute discrimination, if, by virtue of the nature of the professional activity or the conditions under which it is pursued. Such a characteristic constitutes an essential and decisive professional requirement, provided that the purpose is legitimate and the requirement is proportionate and noting that the employer's intention to take into account the wishes of the client that his services should no longer be provided by the employee. Namely to tie an Islamic headscarf, should not be regarded as an essential and decisive professional requirement, within the meaning of Article 4 (1) of the EED.

In the cases discussed above, it is important to note that potential discrimination against Muslim women is appreciated taking into consideration the intersection of three grounds - religion and belief, gender and ethnic origin or race. We can see cases of discrimination undoubtedly related to the features of Islamophobia, which exhibits hostility to religion and culture. At the same time, there is gender discrimination as the Islamic headscarf is exclusively associated with a Muslim woman (Vakulenko 2007). It is noteworthy, that many Muslims in Europe suffer discrimination in employment, education and housing, whatever their ethnicity and / or religion is, they are discriminated against because of their Islamophobia and racist and xenophobic intolerance, as the two elements are often intertwined in the positive findings of the European Monitoring Centre on Racism and Xenophobia (2006).

It is noteworthy, that this situation, where the employer sets the rules and demands religious neutrality for the employee's outfit, results in different experiences for a Muslim man or a Christian woman for example (Xenidis 2018). The requirement for a policy of neutrality at work disproportionately affects a Muslim woman who ties an Islamic headscarf as a mandatory religious attribute; however, no any discrimination influence is to the other employees whose religious commitments or beliefs are not expressed in clothing (Samira Achbita v. G4S Secure Solutions NV 2017).

The Report on the state of fundamental rights provided by European Union Agency for Fundamental Rights (2017) shall state, that there are too many people for whom fundamental rights remain an abstract statutory concept rather than a set of effective and practical tools that can change and transform their daily lives in the EU and for the Member States. While still not explicitly addressing multiple discrimination in legislative and policy measures, it is still not clearly addressing multiple discrimination, and should be recognized as multiple and intersectional discrimination in order to make it possible to combat discrimination, to continue following the equal treatment and sustainable development in employment. 


\section{ENTREPRENEURSHIP AND SUSTAINABILITY ISSUES}

ISSN 2345-0282 (online) http://jssidoi.org/jesi/

2019 Volume 7 Number 2 (December)

http://doi.org/10.9770/jesi.2019.7.2(31)

\section{Religious freedom in the workplace under the case law of ECtHR and international law}

While analyzing the case law of the ECtHR on the ground of religious freedom in the workplace, it can be seen that in the case Eweida and Others $v$. the United Kingdom (2013) the right to freedom to express one's religion or belief while wearing a religious symbol in the workplace was recognized. The right to practice religion was not adequately protected by the state authorities because it was not allowed to carry the cross in public in the workplace. In addition, it is important to note that when deciding this case, ECtHR had to weigh the rights of applicants and the legitimate interests of their employers in the public and private sectors and decide whether the applicant's right to freedom of religion was sufficiently protected by the domestic law.

The applicant was employed in a private company British Airways, in the position of check-in for passengers. With the change in airline uniforms, her ever-worn neck-cross religious symbol - the cross, became public and was in contradiction with the rules of wearing the uniform and the corporate image. After several warnings, the woman was suspended from work until she decided to obey the rules. However, the case went public and British Airways hurried to change the rules and allowed to wear a pendant with a cross at work. The applicant was not dismissed but the employer transferred her to the other position where there was no direct contact with the airline customers.

Mrs. Nadia Eweida filed a complaint based on Article 9 of the ECHR on the right to freedom of thought, conscience and religion, both individually and in combination with Art. 14, on religion discrimination, on the grounds that the United Kingdom did not guarantee its right to religion. Article 9 (ECHR) specifically related to religious freedom, the protection afforded by this provision was much broader and encompassed all personal, political, philosophical, moral, religious beliefs, and included ideas, various philosophical beliefs, individually denoting a person's religious faith, as well as each individual's way of understanding his or her individual and social life.

ECtHR rendered a decision denying that the applicant's right to practice her religion while wearing a religious symbol would have been defended by the absence of specific provisions in the domestic law, however the submitted conclusion was that in that particular case. The right balance had not been reached between Nadia Eweida's desire to practice her religious faith and to express it in a way that was known to others and the employer's desire to uphold a particular corporate image (regardless of the legitimacy of that purpose). The decision was noted that British Airways employees were allowed to wear religious clothing, such as a turban or hijab, and the company image was not threatened. The company later changed the rules for wearing the uniform to allow visible jewellery with religious symbolism to show that the previous ban was not vital.

Therefore, it can be concluded that in the case law of the CJEU and the ECtHR on discrimination in the workplace on the grounds of religion, different positions are taken, the use of different religious signs is controversial, noting that they can be of different sizes and meanings. ECtHR seems to tacitly recognise the phenomenon of intersectional discrimination, and in the case Timishev v. Russia (2005) it was determined that ethnicity and race are related and overlapping concepts. Whereas the notion of race is rooted in the idea of biological classification of human beings into subspecies according to morphological features such as skin colour or facial characteristics, ethnicity has its origin in the idea of societal groups marked by common nationality, tribal affiliation, religious faith, shared language, or cultural and traditional origins and backgrounds (Timishev v. Russia 2005).

Arousing controversies around laws banning religious clothing or symbols at work or in public spaces, such bans risk disproportionally affecting Muslim women who wear religious clothing. However, even where such laws do not exist, hate-motivated discrimination, harassment or violence against members of a certain religion who wear 


\section{ENTREPRENEURSHIP AND SUSTAINABILITY ISSUES}

ISSN 2345-0282 (online) http://jssidoi.org/jesi/

2019 Volume 7 Number 2 (December)

http://doi.org/10.9770/jesi.2019.7.2(31)

religious clothing can have an impact on the right to freedom of religion or belief; this can affect, in particular, Muslim women, Sikhs and Jewish men (European Union Agency for Fundamental Rights 2018).

The constant research conducted by the European Union Agency for Fundamental Rights has identified a number of stereotypes which are recurring in the various Member States, related e. g. to clothing's, in particular with prejudice against the wearing of scarves. Stereotypes about disability and the belief that disability can be fictitious or that older people only pretend to be ill, cultural stereotypes and the belief that HIV /AIDS is prevalent among ethnic or sexual minorities. Cross-systematic application of multidimensional intersectional discrimination, taking all of the grounds of discrimination together, not regulated at legislative level a multidimensional approach to the grounds of discrimination would allow a proper assessment of all cases of discrimination (Carrera et al. 2017).

At the level of international law, intersectionality is officially recognised by the Convention on the Elimination of All Forms of Discrimination against Women Committee as a pertinent concept for understanding the scope of State Parties' obligation to eliminate discrimination (European Union Agency for Fundamental Rights 2018). The Committee stated that, States parties must legally recognise and prohibit such intersecting forms of discrimination and their compounded negative impact on the women concerned (CEDAW 2010).

During the last year, the United Nations Human Rights Committee adopted views in three cases against France regarding religious clothing: two cases concerning the prohibition on wearing a niqab in public (Miriana Hebbadj v. France 2018, Sonia Yaker v. France 2018) and one regarding refusal to allow a worker in a childcare centre to wear an Islamic headscarf (F.A. v. France 2018). In all three cases, the committee found a violation of the right to religion (Article 18 of the ICCPR) and intersectional discrimination on the grounds of gender and religion (Article 26 of the ICCPR).

\section{Conclusions}

In principle, although various legal acts recognize the need to ensure the recognition of multiple and intersectional discrimination and the adoption of the Equal Treatment Directive, the proper fight against discrimination has to be ensured, which would provide a comprehensive legal framework. Currently, the problem remains unresolved due to the lack of unanimity as required by the EU Council, in order to be possible to adopt the horizontal resolution and thus multiple gaps in the legal framework for discrimination remain in EU antidiscrimination law and remains clearly grounded, with a certain hierarchy of grounds for discrimination.

There is also the need to recognize multiple, intersectional discrimination, for which the identification, comparison and overall analysis of the grounds of discrimination is of great importance, as this may highlight the disadvantage to which the individual is discriminated, while ensuring the practical implementation of fundamental rights.

There are various stereotypes of perception related to personal characteristics or characteristics such as religion and ethnicity and migrant status, culture, age, gender, or various social groups or individuals can experience any combination of these characteristics and multiple or intersectional discrimination. Notably, comparisons of basics and complex analysis can help to better understand how people experience discrimination in their daily lives, as well as helping to raise awareness of unconscious discrimination, to break down stereotypes and prejudices and, accordingly, to devise legal and political instruments to ensure effective equality.

The elimination of discrimination based on a single cause is not expected to highlight the wide variety of cases of multiple discrimination that people in the European Union experience in their daily lives. The vagueness and 


\section{ENTREPRENEURSHIP AND SUSTAINABILITY ISSUES}

ISSN 2345-0282 (online) http://jssidoi.org/jesi/ 2019 Volume 7 Number 2 (December)

http://doi.org/10.9770/jesi.2019.7.2(31)

imprecision of the term multiple discrimination causes the issue of legal relevance and benefit of antidiscrimination.

It is noteworthy, that regardless of the interaction between social categories, the theory of interactional attitudes and disregarding the basics of religion, gender, and ethnicity, intersectional interaction and social identity, the effect of a synergy of these factors acting together, on a Muslim woman, remains invisible and undisclosed. Such prohibitions appear to have a disproportionate impact on Muslims who choose to wear certain clothing because of their religious identity or beliefs, and may discriminate not only on the basis of religion but also on the basis of ethnicity and gender.

In theory, all Member States can tackle multiple discrimination within the employment market. It is true that most Member States do not consider that way, although multiple discrimination can occur in any area, however, according to CJEU case law cases it is most commonly related to the employment. There is a case law of the ECtHR, United Nations Human Rights Committee views in this area, sufficient data have been collected, and a research has been done. Recognition of the multiple, intersectional discrimination will be an efficient mean for further sustainable business development and combine all ground of discrimination especially in the case of complex inequality at the area of employment.

\section{References}

Asma Bougnaoui v. Micropole SA (2017) C-188/15.

Carrera, S., Guild, E., Vosyliūtè, L, \& Bard, P. 2017. Towards a Comprehensive EU Protection System for Minorities. Retrieved from http://www.europarl.europa.eu/RegData/etudes/STUD/2017/596802/IPOL STU(2017)596802 EN.pdf

CEDAW. 2010. General Recommendation No. 28 on the Core Obligations of States Parties under Article 2 of the Convention on the Elimination of All Forms of Discrimination against Women. Retrieved from https://www2.ohchr.org/english/bodies/cedaw/docs/CEDAWC-2010-47-GC2.pdf

Council of Europe Parliamentary Assembly. 2012. Resolution 1887 multiple discrimination against Muslim women in Europe: for equal opportunities. Retrieved from http://www.assembly.coe.int/nw/xml/XRef/Xref-XML2HTML-en.asp?fileid=18921\&lang=en

Council of Europe. 1950. European Convention for the Protection of Human Rights and Fundamental Freedoms. Retrieved from https://www.echr.coe.int/Documents/Convention_ENG.pdf

European Monitoring Centre on Racism and Xenophobia. 2006. Muslims in the European Union - Discrimination and Islamophobia. Austria: Printer MANZ CROSSMEDIA GmbH \& Co KG.

European Parliament and Council. 2006. Directive 2006/54/EC on the implementation of the principle of equal opportunities and equal treatment of men and women in matters of employment and occupation (recast). Retrieved from http://data.europa.eu/eli/dir/2006/54/oj

European Parliament. 2016. Resolution on refugees: social inclusion and integration into the labour market. Retrieved from http://www.europarl.europa.eu/doceo/document/TA-8-2016-0297 EN.html

European Parliament. 2016. Resolution on application of Council Directive 2000/78/EC of 27 November 2000 establishing a general framework for equal treatment in employment and occupation ('Employment Equality Directive'). Retrieved from http://www.europarl.europa.eu/doceo/document/TA-8-2016-0360_EN.html 


\section{ENTREPRENEURSHIP AND SUSTAINABILITY ISSUES}

ISSN 2345-0282 (online) http://jssidoi.org/jesi/

2019 Volume 7 Number 2 (December)

http://doi.org/10.9770/jesi.2019.7.2(31)

European Parliament. 2016. Resolution on the implementation of the UN Convention on the Rights of Persons with Disabilities, with special regard to the Concluding Observations of the UN CRPD Committee. Retrieved from http://www.europarl.europa.eu/doceo/document/TA-8-2016-0318_EN.html

European Parliament. 2016. Resolution on poverty: a gender perspective. Retrieved from http://www.europarl.europa.eu/doceo/document/TA-8-2016-0235_EN.html

Eurostat. 2019. Sustainable development in the European Union - Monitoring report on progress towards the SDGs in an EU context. Luxembourg: Publications Office of the European Union. https://doi.org/10.2785/4526

European Union Agency for Fundamental Rights. 2018. Handbook on European non-discrimination law. Luxembourg: Publications Office of the European Union. https://doi.org/10.2811/58933

European Union Agency for Fundamental Rights. 2017. Fundamental Rights Report 2017 FRA Opinions. Retrieved from https://fra.europa.eu/sites/default/files/fra_uploads/fra-2017-fundamental-rights-report-2017-opinions_en.pdf

European Union Agency for Fundamental Rights. 2019. Fundamental Rights Report 2019. Luxembourg: Publications Office of the European Union. https://doi.org/10.2811/903190

European Union Commission. 2008. Proposal for a Council Directive on implementing the principle of equal treatment between persons irrespective of religion or belief, disability, age or sexual orientation. Retrieved from https://eur-lex.europa.eu/legalcontent/en/TXT/?uri=CELEX\%3A52008PC0426

European Union Council. 2000. Directive 2000/43/EC implementing the principle of equal treatment between persons irrespective of racial or ethnic origin. Retrieved from http://data.europa.eu/eli/dir/2000/43/oj

European Union Council. 2000. Directive 2000/78/EC establishing a general framework for equal treatment in employment and occupation. Retrieved from https://eur-lex.europa.eu/eli/dir/2000/78/oj

Eweida and Others v. The United Kingdom (2013) 48420/10, 59842/10, 51671/10, 36516/10.

F.A. v. France (2018) CCPR/c/123/D/2662/2015.

Miriana Hebbadj v. France, (2018) CCPR/C/123/D/2807/2016.

Opinion of Advocate General Eleanor V. E. Sharpston (2016) in Case C-188/15.

Opinion of Advocate General Juliane Kokott (2016) in Case C-157/15.

Samira Achbita v. G4S Secure Solutions NV (2017) C-157/15.

Schouten, M.J. 2019. Undoing gender inequalities: insights from the Portuguese perspective. Insights into Regional Development, (2), 8598. https://doi.org/10.9770/ird.2019.1.2(1)

Sonia Yaker v. France (2018) CCPR/C/123/D/2747/2016.

Timishev v. Russia (2005) 55762/00, 55974/00.

United Nations General Assembly. 1966. International Covenant on Civil and Political Rights. Retrieved from https://treaties.un.org/doc/publication/unts/volume\%20999/volume-999-i-14668-english.pdf

United Nations General Assembly. 1979. Convention on the Elimination of All Forms of Discrimination against Women. Retrieved from https://treaties.un.org/doc/Treaties/1981/09/19810903\%2005-18\%20AM/Ch IV 8p.pdf

United Nations General Assembly. 2006. Convention on the Rights of Persons with Disabilities. Retrieved from https://www.un.org/disabilities/documents/convention/convoptprot-e.pdf

United Nations General Assembly. 2015. Resolution transforming our world: the 2030 Agenda for Sustainable Development. Retrieved from https://www.un.org/ga/search/view_doc.asp?symbol=A/RES/70/1\&Lang=E 


\section{ENTREPRENEURSHIP AND SUSTAINABILITY ISSUES}

ISSN 2345-0282 (online) http://jssidoi.org/jesi/

2019 Volume 7 Number 2 (December)

http://doi.org/10.9770/jesi.2019.7.2(31)

Vakulenko, A. 2007. Islamic Headscarves and the European Convention on Human Rights: An Intersectional Perspective. Social \& Legal Studies, 16(2): 183-199.

Xenidis, R. 2018. Multiple Discrimination in EU Anti-Discrimination Law: Towards Redressing Complex Inequality? in Belavusau, U.; Henrard, K. (Ed.). EU Anti-Discrimination Law Beyond Gender. Oxford: Hart, 41-74. https://doi.org/10.5040/9781509915033

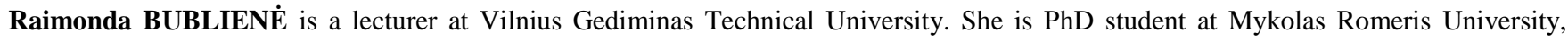
Institute of International and European Union Law. Her research interests include business law and anti-discrimination law. She published 6 articles, 2 textbooks and made 3 presentations in international conferences. She also took part in 15 internship programs in Belgium, Spain, Greece, Portugal, Croatia, Slovenia, Italy, Morocco, Egypt.

ORCID ID: orcid.org/0000-0003-3576-3975.

Vaidas JURKEVIČIUS is an associate professor at Mykolas Romeris University and attorney-at-law at law firm "BSP Legal". He obtained PhD degree in law from Mykolas Romeris University in 2014 (the topic of PhD Thesis was related to the unauthorised agency from a comparative perspective). His research interests include comparative law, private law and agency law. He published 15 articles in peer-reviewed journals, 3 textbooks (one of them was recognised as the best in the academic year of 2015/2016) and made 8 presentations in international conferences. He also took part in 12 internship programs in Canada, Norway, Finland, Switzerland, Sweden, Denmark, Greenland, the United Kingdom, Denmark, Italy and Austria. His internship at the University of Geneva was rated as one of the 5 most successful.

ORCID ID: orcid.org/0000-0002-1443-3427.

Register for an ORCID ID:

https://orcid.org/register

Copyright (C) 2019 by author(s) and VsI Entrepreneurship and Sustainability Center This work is licensed under the Creative Commons Attribution International License (CC BY). http://creativecommons.org/licenses/by/4.0/

(c) (7) Open Access 